\title{
Respon Fikih terhadap Perkembangan Teknologi Rukyat
}

\author{
Sakirman \\ Fakultas Syariah IAIN Metro \\ Jl. Ki Hajar Dewantara Kampus 15A, Iringmulyo, Metro, Lampung, 34111 \\ E-mail: sakirman87@gmail.com
}

\begin{tabular}{llll} 
Submit & $: 15$ Oktober 2019 & Diterima & $:$ 18 Mei 2020 \\
Revisi & $: 17$ April 2020 & Terbit & $:$ 03 Juni 2020 \\
\hline
\end{tabular}

\begin{abstract}
Abstrak: Metode penentuan awal bulan hijriah yang mengacu pada regularitas hilal adalah rukyat. Isu sentral gangguan rukyat adalah masalah kontras visual cahaya syafak yaitu perbedaan terang atau warna antara objek dengan latar depannya. Hilal yang redup, tipis, dan warnanya hampir sama dengan langit di sekelilingnya menjadikan mata manusia dalam keadaan normal tidak sanggup melihat hilal tanpa alat bantu rukyat. Teknologi rukyat mengalami lompatan yang cukup signifikan dengan munculnya teknologi optik seperti teleskop rukyat. Teleskop tidak sanggup mengidentifikasi hilal yang sangat redup, karena ketika cahaya hilal diperkuat cahaya syafak pun diperkuat. Akibatnya cahaya hilal pun tetap sulit dikenali. Teknologi rukyat yang memungkinkan untuk dipakai adalah digital imaging, dibantu dengan perangkat lunak dapat berfungsi meningkatkan kontras agar hilal terlihat secara kasat mata. Teknologi digital imaging memiliki peran penting sebagai media verifikator atas kesaksian seseorang melihat hilal tapi diragukan validitasnya. Dalam menyikapi perkembangan teknologi yang dipakai untuk rukyatulhilal, ulama fikih baik klasik maupun kontemporer memberikan respon positif terkait penggunaan alat bantu rukyat yang bertujuan untuk memudahkan proses rukyatulhilal, terutama dalam hal memperjelas objek pandang hilal agar hilal dapat dilihat dengan mata visual.
\end{abstract}

Kata kunci: Rukyat, teknologi, digital imaging, hilal.

Abstract: The method used to determine the beginning of the Islamic month which refers to the hilal regularity is called rukyat. The central issue of rukyat disruption is the problem of visual contrast of sky twilight, namely the difference in light or the color between the object and the foreground. The hilal (the new crescent moon) is dim, thin, and its color is almost the same as the sky around it so it makes the human eyes in a normal state unable to see directly the hilal without using the tools. Moreover, the technology of rukyat has developed significantly by adventing the optical technology named the rukyat telescope. However, this telescope is not able to identify hilal (the new moon), because it is only functioned to collect the light; so, when the twilight (syafak) light is strengthened, the hilal light is also equally strengthened. Furthermore, rukyat technology that is possibly used is digital imaging assisted by software that works to increase the light contrast so that the hilal can be seen by the visual eyes. Finally, digital imaging technology has an important role as a media verifier of the testimony stated by someone seeing the hilal, contrarily, its validity is doubtful. In responding to the development of technology used for finding the new crescent (rukyatulhilal), both classical and contemporary figh scholars give a positive responses related to the use of rukyat tools that aim to facilitate the process of seeing the crescent (rukyatulhilal), especially in terms of clarifying the crescent sight object so that the new moon can be seen with the visual eye.

Keywords: Rukyat, technology, digital imaging, hilal. 


\section{Pendahuluan}

Metode penentuan awal bulan hijriah dengan melakukan pengkajian terhadap hilal adalah rukyat. ${ }^{1}$ Baik dilakukan dengan alat bantu teknologi maupun tidak dilaksanakan dengan prosedur pengamatan yang baku. ${ }^{2}$ Fenomena munculnya hilal relatif singkat sesaat setelah Matahari terbenam, namun sangat berarti dalam sistem penanggalan hijriah sebagai tanda pergantian Bulan dari bulan lama menuju bulan baru yakni fase Bulan sebagai penentu perjalanan hari pada saat ijtima' ${ }^{3}$ Rukyat secara visual bukan suatu perkara yang mudah karena hilal yang umurnya sangat muda sulit dikenali. Semakin muda umurnya semakin tipis dan semakin sulit melihatnya. ${ }^{4}$ Terdapat beberapa kendala rukyatulhilal berupa faktor alam maupun peralatan yang digunakan saat rukyatulhilal berlangsung. Kesulitan pengamatan hilal juga dipengaruhi oleh tiga aspek seperti jarak hilal yang jauh dengan sudut pandang yang terlalu kecil, kontras cahaya hilal yang redup, dan faktor penghalang latar depan seperti cahaya syafak. ${ }^{5}$ Rukyat yang dilakukan secara visual seringkali mengalami kesulitan karena kondisi langit dan faktor pengganggu lainnya. Peran teknologi dalam pengamatan hilal penting dirumuskan dengan tujuan terlihatnya hilal.

Beberapa kajian yang membahas tentang penggunaan teknologi dalam rukyatulhilal di antaranya; Pertama, Thierry Legault, dalam buku Astrophotography, ${ }^{6}$ memperkenalkan teknik fotografi astronomi untuk pengamatan hilal yang secara praktik kontribusi ilmiah dari teknik fotografi astronomi sangat membantu dalam rukyatulhilal. Teknik fotografi astronomi Legault belum menyelesaikan masalah karena faktor peralatan yang kurang mendukung bahkan masih menjadi perdebatan dalam aspek fikih. Kedua, S. Farid Ruskanda menulis tentang “Teknologi Rukyat Secara Objektif”. Ruskanda menawarkan empat alternatif teknologi rukyat secara objektif; Pertama, perangkat teleskop kamera video untuk cahaya tampak; Kedua, perangkat untuk sinar infra merah secara pasif; Ketiga, perangkat infra merah untuk penyiaran hilal menggunakan laser aktif; Keempat, memanfaatkan perangkat radar. Ketiga alternatif pertama menggunakan teknologi opto-elektronika tidak dapat mengatasi kendala cuaca ekstrem seperti gangguan awan, cahaya syafak, serta faktor pengganggu lainnya. Alternatif lain adalah penggunaan gelombang mikro yang dapat dimanfaatkan untuk mengatasi gangguan utama dalam rukyatulhilal. Kecerlangan cahaya hilal yang redup dengan memanfaatkan teleskop radar dengan jarak panjang gelombang radio 400.000 dari Bumi kilometer akan diterima Bulan dan memantulkan ke Bumi. Selanjutnya, data yang diterima dapat diproses dengan metode digital imanging atau metode pengolahan gambar sehingga dapat dilihat secara visual. Setelah hilal terlihat secara visual langkah selanjutnya adalah menyiarkan melalui tayangan televisi atau media lain yang dapat digunakan untuk menyampaikan informasi tentang status hilal terkait dengan ketinggian hilal, jarak sudut atau elongasi, dan umur hilal.

Susiknan Azhari, Ensiklopedi Hisab Dan Rukyat (Yogyakarta: Pustaka Pelajar, 2008), 183.

Mutoha Arkanuddin dan Muh. Ma'rufin Sudibyo, "Kriteria Visibilitas Hilal Rukyatul Hilal Indonesia (RHI) (Konsep, Kriteria, Dan Implementasi)," Al-Marshad: Jurnal Astronomi Islam Dan Ilmu-Ilmu Berkaitan 1, no. 1 (n.d.): 36.

3 Departemen Agama, Pedoman Perhitungan Awal Bulan Qamariyah (Jakarta: Direktorat Jenderal Pembinaan Kelembagaan Agama Islam, 1995), 3.

4 Thomas Djamaluddin dkk, Hisab Rukyat Di Indonesia Serta Permasalahannya (Jakarta: Badan Meteorologi Klimatologi dan Geofisika, 2010), 85.

5 Danang Endarto, Pengantar Kosmografi (Surakarta: Lembaga Pengembangan Pendidikan UNS bekerjasama dengan UNS Press, 2005), 217.

Thierry Legault, “Astrophotography” (Paris: Groupe Eyrolles, 2013), 1-225.

7 S. Farid Ruskanda Dkk, Rukyat Dengan Teknologi; Upaya Mencari Kesamaan Pandangan Tentang Penentuan Awal Ramadhan Dan Syawal (Jakarta: Gema Insani Press, 1994), 23-35. 
Gagasan ideal Ruskanda tersebut menarik bahkan usulan tersebut disampaikan dalam forumforum ilmiah namun masih belum disepakati. Gagasan tersebut memungkinkan dalam praktek tetapi gagasan tersebut anggaran yang digunakan cukup mahal. Ketiga, Moedji Raharto menulis tentang "Teknologi Optik sebagai Pembantu Penetapan Awal Bulan Hijriyah/Qomariyah". Raharto meyebutkan bahwa peran teleskop optik dalam rukyat dapat membantu pengamatan hilal sehingga dapat dicapai objektivitas rukyatulhilal. Tujuan rukyatulhilal dengan teleskop optik adalah menyamakan pendapat tentang objek hilal yang dapat diterima oleh pengamat dalam hal ini adalah pengamal rukyat sehingga objek hilal dapat diketahui dan kesalahan dalam mengamati hilal dapat dihindari akibat dari cahaya hilal yang tipis dan kecerlangan cahaya syafak yang sangat terang. Solusi alternatif yang ditawarkan Raharto dalam tulisan tersebut adalah penggunaan teleskop optik dalam rukyatulhilal dengan cara perbaikan kontras antara hilal yang tipis dengan cahaya syafak. Langkah yang dapat ditempuh adalah mempertinggi $F_{R}=$ (Fid), $F$ adalah fokus atau jarak dari titik api teropong sedangkan $d$ adalah diameter objektif teropong. $\mathrm{F}$ ratio, $\mathrm{F}_{\mathrm{R}}$ adalah indikasi dari kecerlangan pada bidang fokus teropong. Jika diameter objektif pada teropong diperkecil maka kecerlangan akan berkurang dan bergeser pada bagian kecerlangan dapat terdeteksi dengan baik. Pada prateknya, tawaran Raharto tidak dapat menyelesaikan masalah, karena penggunaan teleskop optik dalam rukyatulhilal hanya berfungsi untuk mengumpulkan cahaya, kontras hilal diperkuat cahaya syafak juga sama diperkuatnya.

Tulisan ini lebih menekankan pada bagaimana respon fikih terhadap perkembangan teknologi dalam rukyatulhilal yang berujung pada faktor kunci keberhasilan rukyat. Langkah yang dapat ditempuh adalah memotret hilal dengan kamera digital kemudian citra hilal dianalisis dengan perangkat lunak (software). Kajian ini merupakan langkah awal yang berkontribusi pada rukyat visual. Hasil dari kajian ini diharapkan dapat meningkatkan validitas rukyat atas kesaksian rukyat yang diragukan. Visibilitas hilal terus mengalami perkembangan sesuai dengan kajian astronomi. Tulisan ini memberikan kontribusi positif terkait dengan kriteria visibilitas hilal sebagai syarat penentuan awal bulan hijriah di Indonesia agar kriteria visibilitas hilal memiliki landasan ilmiah yang kokoh.

\section{Ruang Lingkup Rukyatulhilal}

\section{Pengertian Rukyat}

Secara bahasa (etimologi) kata rukyat (رؤية) adalah bentuk mașdar/kata benda dari kata kerja ra'ā (رأى)/melihat. Kata ra'ā (رأى) mempunyai murādif/sinonim dan makna yang bermacam-macam, antara

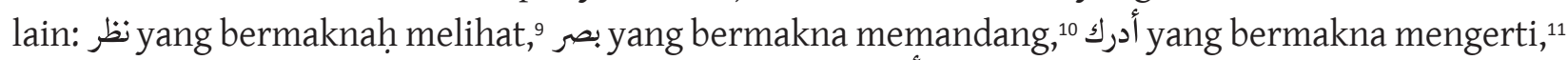
dan حسب yang bermakna menduga, mengira. ${ }^{12}$ Kata ra'a (رأى) juga memiliki beberapa bentuk maṣdar/ kata benda dengan arti yang berbeda-beda. Bentuk maṣdar dari kata ra'ā antara lain: rukyat (رؤية)

8 Choirul Fuad Yusuf dan Bashori A Hakim, Hisab Rukyat Dan Perbedaannya (Jakarta: Proyek Peningkatan Pengkajian Kerukunan Hidup Umat Beragama, Puslitbang Kehidupan Beragama, Badan Litbang Agama dan Diklat Keagamaan, Departemen Agama RI, 2004), 145-80.

9 Ahmad Warson Munawwir, Al-Munawwir Kamus Arab-Indonesia (Surabaya: Pustaka Progresif, 1997), 460.

10 Ahmad bin Muhammad bin 'Alî al-Maqrî al-Fayyûmî, al-Misbâh Al-Munîr Fî Gharîb al-Syarh al-Kabîr Li Al-Râfi'î (Beirut: alMaktabah al-'Ilmîyah, n.d.), 247.

11 Abû Hilâl al-hasan bin 'Abdillâh bin Sahal bin Sa'îd bin Yahyâ bin Mahrân Al-'Askarî, Mu'jam Al-Furûq Al-Lughawîyah (Muassasah al-Nasyr al-Islâmî, 1412), 543.

12 Ahmad Warson Munawwir, Al-Munawwir Kamus Arab-Indonesia, 460. 
yang berarti "النطر بالعين والقلب" yakni melihat dengan mata atau dengan hati;13 ra'yan (رأيا) yang berarti

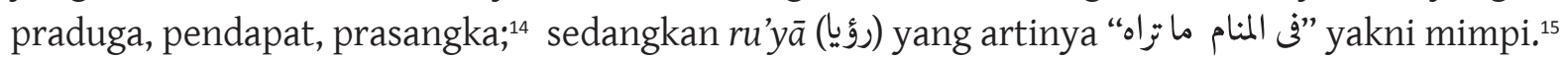

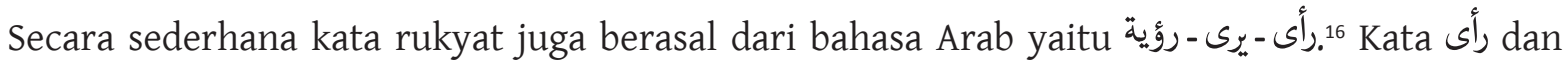
tașrif-nya mempunyai banyak arti, antara lain: melihat, mengerti, mengetahui, memperhatikan, berpendapat, menduga, yakin, dan bermimpi. Ketika kata رأى dan tashrif-nya dirangkaikan dengan objek/mafūl bih yang fisikal, maka mașdar-nya adalah rukyat (رؤية), dan mempunyai arti tunggal yaitu melihat dengan mata kepala, baik menggunakan mata kepala maupun dengan alat pembesar. ${ }^{17}$

Dalam aspek lain, kata dasar أى أرؤي dapat berubah sesuai dengan konteksnya menjadi أر أر dara bahasa berakar dari kata رأى dapat berarti melihat secara visual, namun dapat juga berarti melihat bukan dengan cara visual seperti melihat dengan logika, pengetahuan, dan kongnitif. Kata jika digabungkan dengan orang kedua sebagai subjeknya maka kata tersebut berubah menjadi ترى yang bermakna kamu melihat atau kamu memperhatikan.

Kata rukyat juga dapat berarti melihat secara kongnitif yaitu melihat dengan kesadaran nalar dan ilmu pengetahuan yang secara statistik ternyata menunjukkan isyarat bahwa umat Islam semestinya lebih menggunakan kemampuan intelektualnya dari pada mengandalkan penglihatan visualnya. ${ }^{18}$ Kata rukyat dengan konsep bahasa di atas penggunaannya jarang dipakai. Karena kata rukyat sudah merupakan istilah yang biasa dipakai oleh para ahli fikih dan masyarakat luas untuk pengertian melihat hilal yang berkaitan dengan penentuan awal bulan hijriah. ${ }^{19}$

Menurut istilah, makna rukyat paling umum bermakna melihat dengan mata kepala, ${ }^{20}$ rukyat juga berarti observasi atau pengamatan terhadap benda-benda langit. ${ }^{21}$ Rukyat merupakan metode ilmiah yang akurat, terbukti dengan berkembangnya ilmu falak (astronomi) pada zaman keemasan Islam. Para ahli terdahulu melakukan pengamatan secara serius dan berkelanjutan yang akhirnya menghasilkan tabel-tabel astronomi yang terkenal dan hingga kini masih menjadi rujukan primer. ${ }^{22}$ Dalam khazanah fikih, kata rukyat lazim disertai dengan kata hilal sehingga menjadi rukyatulhilal yang berarti melihat hilal adalah suatu kegiatan atau usaha mengamati hilal di langit sebelah barat sesaat setelah Matahari terbenam menjelang awal bulan baru, khususnya menjelang bulan Ramadan, Syawal dan Zulhijah. ${ }^{23}$ Jadi secara umum, rukyatulhilal adalah melihat atau mengamati hilal pada saat Matahari terbenam menjelang bulan hijriah dengan mata atau alat bantu rukyat. Dalam dunia astronomi rukyat dikenal dengan istilah observasi. Sesuai dengan yang dicontohkan Nabi, rukyat dilakukan secara visual dan tanpa alat bantu rukyat, tapi pengalaman rukyat seperti ini sangat individual dan subjektif. ${ }^{24}$

Makna dan konsep definisi rukyat mengalami perkembangan sesuai dengan fungsi dan kepentingan penggunaannya. Pada awalnya, pengertian rukyat terbatas pada satu aktifitas melihat hilal saat Matahari terbenam pada akhir bulan Sya'ban atau Ramadan dalam rangka menentukan

13 Ibnu Manzûr, Lisân Al-'Arab, 17th ed. (Kairo: Dâr al-Ma'ârif, n.d.), 1537.

14 Atabik Ali dan Ahmad Zuhdi Muhdlor, Kamus Kontemporer Arab-Indonesia (Yogyakarta: Multi Gaya Grafika, 1998 ), 950.

15 Lois Ma'luf, Al-Munjid Fî Al-Lughah Wa Al-A'lâm (Beirut: Dâr al-Masyriq, 1989), 243.

16 Ahmad Warson Munawwir, Al-Munawwir Kamus Arab-Indonesia, 460.

17 A. Ghazali Masroerie, Penentuan Awal Bulan Qamariyah (Jakarta: Lajnah Falakiyah Nahdlatul Ulama, 2011), 2.

18 Tono Saksono, Mengkompromikan Rukyat \& Hisab (Jakarta: Amythas Publicita, 2007), 86.

19 Departemen Agama RI, Pedoman Teknik Ru'yat (Jakarta: Proyek Pembinaan Badan Peradilan Agama, 1994), 1.

20 Azhari, Ensiklopedi Hisab Dan Rukyat, 183.

21 Muhyiddin Khazin, Kamus Ilmu Falak (Yogyakarta: Buana Pustaka, 2014), 69.

22 Susiknan Azhari, Ilmu Falak; Perjumpaan Khazanah Islam Dan Sains Modern (Yogyakarta: Suara Muhammadiyah, 2007), 129-30.

23 Muhyiddin Khazin, Ilmu Falak Dalam Teori Dan Praktik (Yogyakarta: Buana Pustaka, 2004), 173.

${ }_{24}$ Farid Ruskanda, 100 Masalah Hisab \& Rukyat; Telaah Syariah, Sains Dan Teknologi (Jakarta: Gema Insani Press, 1996$), 41$. 
awal bulan hijriah. Pengertian tersebut menunjukkan bahwa rukyat hanya dilakukan pada akhir bulan Sya'ban dalam rangka menentukan awal bulan Ramadan dan pada akhir bulan Ramadan dalam rangka menentukan awal bulan Syawal.

Perkembangan selanjutnya, rukyat tidak terbatas pada aktifitas melihat hilal pada akhir Sya'ban dan Ramadan, namun juga pada bulan-bulan lain terutama menjelang awal bulan yang berkaitan dengan waktu pelaksanaan ibadah atau hari-hari besar umat Islam, seperti bulan Zulhijah, Muharam, Rabi'ul Awal, dan Rajab. Bahkan untuk kepentingan koreksi serta melatih keterampilan para praktisi rukyat, aktifitas melihat hilal dilakukan setiap pergantian bulan pada kalender hijriah. Dengan demikian, pelaksanaan rukyat tidak terbatas dilakukan pada awal Ramadan dan Syawal, tetapi juga dilakukan setiap menjelang pergantian bulan baru pada kalender hijriah.

\section{Pengertian Hilal}

Pakar linguistik Arab abad ke-7 al-Khalil Ibnu Ahmad al-Farāhịī̄, menguraikan kata hilal dalam Kitāb al-'Ayn, bahwa hilal berasal dari kata halla (هل) yang berarti dia muncul. Hilal juga berasal dari kata uhilla (أهل) (dia kelihatan). ${ }^{25}$ Selain al-Farāhidī, ahli linguistik Arab lainnya seperti Rāgib alIṣbahāni menjelaskan bahwa hilal adalah bulan sabit berarti bulan yang khusus kelihatan pada hari pertama dan kedua dalam sebuah bulan, setelah itu maka dinamakan qamar (bulan). ${ }^{26}$

Ibnu Manzūur dalam Lisān al-'Araby menguraikan asal-usul dan makna kata hilal. Menurutnya, hilal adalah bulan sabit pada hari pertama dan kedua bulan kamariah atau dua malam terakhir bulan kamariah. Keterangan ini menunjukkan bahwa ada proses melihat secara visual terkait dengan bulan sabit atau hilal. ${ }^{27}$ Selanjutnya, al-Fairūz Abādi dalam al-Qāmus al-Muhịt, menjelaskan bahwa yang dimaksud hilal adalah bulan sabit yang tampak pada 2-3 malam dari awal bulan atau 7-2 malam dari akhir bulan. ${ }^{28}$

Dalam Kamus al-Munawwir dijelaskan makna-makna yang terkait dengan asal kata hilal sebanyak dua belas makna, yang secara rinci sebagai berikut: 1) Bulan sabit; 2) Bulan yang terlihat pada awal bulan; 3) Curah hujan; 4) Permukaan hujan; 5) Air sedikit; 6) Warna putih pada pangkal kuku; 7) Cap, selar pada unta; 8) Unta yang kurus; 9) Kulit kelongsong ular; 10) Debu; 11) Ular jantan; 12) Anak muda yang bagus. Senada dengan Kamus al-Munawwir, Harun Nasution dan kawan-kawan, dalam Ensiklopedi Islam Indonesia, telah mengukuhkan temuan-temuan makna yang tertulis dalam kamus tersebut. ${ }^{29}$

Dalam kamus Arabic-English Dictionary karya Hans Wehr, kata hilal bentuk pluralnya ahillah atau ahālil bisa berarti new moons (bulan muda) atau crescent (sabit). Demikian juga dengan John M. Echols dan Hassan Shadily dalam Kamus Inggris-Indonesia, AS Hornby dalam Oxford Advanced Learner's Dictionary of Current English dan Lois Ma'luf dalam al-Munjid..$^{30}$ Definisi seperti ini pun berkembang pula dalam karya-karya berbahasa Inggris seperti Muhammad Baqir Behbudi dalam The Quran: A New Interpretation terjemahan Collin Turner dan A. Yusuf Ali dalam The Holy Qur'an Text: Translation and Commentary. ${ }^{31}$

\footnotetext{
25 al-Khalīl Ibnu Aḥmad Al-Farāḥidi, Kitāb Al-‘Ayn (Beirut: Dār Iḥyā ' al-Turāṣ al-‘Arabi, n.d.), 1017.

26 Rāgīb Al-Iṣbahāàni, Al-Mufradāt (Damascus: Dār al-Qalam, 1992), 843.

27 Manzûr, Lisân Al-'Arab, 227-30.

28 al-Fairuz Abadi, al-Qamus al-Muhit (Beirut: Dar al-Fikr, 1995), 966.

29 Harun Nasution Dkk, Ensiklopedi Islam Indonesia, cet. I (Jakata: Djambatan, 1992), 319.

30 Hans Wehr, Arabic-English Dictionary, 4th ed. (Germany: Otto Harrassonitz, 1994), 1208.

31 Muhammad Baqir Behbudi, The Quran A New Interpretation, 1st ed. (London: Curzon press, 1997), 16.
} 
Referensi lain yang cukup komprehensif dalam mengurai kata hilal adalah karya orientalis B. Lewis V. L. Menage, Ch. Pellat, dan J. Schacht yakni The Encyclopedia of Islam. Dalam buku ini, kata hilal digunakan sebagaimana literatur-literatur asing lainnya yaitu new moons (bulan muda) atau sabit (crescent). . $^{32}$

Dalam Kamus Ilmu Falak, kata hilal atau bulan sabit dalam astronomi dikenal dengan nama crescent, yaitu bagian Bulan yang tampak terang dari Bumi sebagai akibat cahaya Matahari yang dipantulkan olehnya pada hari terjadinya ijtima $\vec{a}$ sesaat setelah Matahari terbenam. Hilal ini dapat dipakai sebagai tanda pergantian bulan kamariah. Apabila setelah Matahari terbenam hilal tampak, maka malam itu dan keesokan harinya merupakan tanggal satu bulan berikutnya. ${ }^{33}$

Dalam Kamus Besar Bahasa Indonesia, kata hilal telah menjadi bahasa baku untuk menyebut bulan sabit atau bulan yang terbit pada tanggal 1 bulan qamariah. ${ }^{34} \mathrm{Hilal}$ menurut bahasa dapat ditarik sebuah simpulan bahwa hilal merupakan bulan sabit yang tampak terlihat di langit sebagai pertanda pergantian bulan baru untuk keperluan ibadah dan muamalah sesaat setelah Matahari terbenam.

\section{Perkembangan Rukyatulhilal}

\section{Rukyat Konvensional}

Rukyat untuk mengetahui fisis hilal telah dicontohkan oleh Nabi pada kesaksian Ibnu Umar bin Arabi. ${ }^{35}$ Rukyat pada saat itu dilakukan secara alamiah dan terbatas pada pengamatan visual. Rukyat pada periode ini tergolong dalam rukyat bil fili. Teknik yang dilakukan terbatas dan sederhana yaitu hanya melihat ke atas ufuk bagian barat yang cukup luas, tanpa mengarahkan pandangan ke suatu posisi tempat hilal berada. Teknik rukyat yang diajarkan oleh Nabi kepada sahabatnya termasuk dalam kategori rukyat yang bersifat konvensional yaitu suatu kebiasaan yang dicontohkan oleh Nabi dan diwariskan kepada generasi selanjutnya.

Adapun prosedur rukyat konvensional yaitu jika pada waktu rukatulhilal setelah Matahari terbenam hilal terlihat maka malam dan esok hari masuk tanggal 1 bulan berikutnya. Sedangkan jika perukyat tidak berhasil melihat fisis hilal maka malam dan esok hari merupakan tanggal 30 bulan yang sedang berlangsung atau dengan kata lain bulan yang sedang berlangsung digenapkan (istikmāl) menjadi 30 hari. Hal ini sejalan dengan hadis yang secara tekstual menyebutkan bahwa melihat fisis hilal secara visual dan menggenapkan bulan hijriah menjadi 30 hari adalah cara yang dipakai oleh Nabi ketika menetapkan awal bulan hijriah, seperti:

$$
\text { ردثنا عبدالله بن مسامة حدثنا مالك عن نافع عن عبد الله بن عمر رضي الله عنهما أن رسول الله صلى الله عليه وسلم ذكر }
$$

Hadis di atas memberikan pengertian bahwa ada dua cara yang dipakai oleh umat Islam sejak zaman Nabi dalam memulai dan mengakhiri ibadah puasa Ramadan. Pertama, dengan metode rukyat

\footnotetext{
32 dkk B. Lewis, The Encyclopedia of Islam, III (Leiden: E.J. Brill, 1971), 379-88.

33 Muhyiddin Khazin, Kamus Ilmu Falak, 30.

34 Departemen Pendidikan dan Kebudayaan, Kamus Besar Bahasa Indonesia, ed. Balai Pustaka (Jakarta, 1989), 307.

35 Ma'ruf Amin, Rukyat Untuk Penentuan Awal Dan Akhir Ramadan Menurut Pandangan Syari'ah Dan Sorotan IPTEK", Dalam Selayang Pandang Hisab Rukyat (Jakarta: Direktorat Jenderal Bimas Islam dan Penyelenggaraan Haji Direktorat Pembinaan Peradilan Agama, 2004), 95.

36 Muhammad bin Isma'il Al-Bukhari, Matn Al-Bukhari (Mesir: Dar Ihya' al-'Arabiyyah, n.d.), 327.
} 
yaitu melihat hilal pada akhir bulan Sya'ban untuk menentukan tanggal 1 bulan Ramadan ketika akan memulai kewajiban puasa, dan melihat hilal pada akhir bulan Ramadan untuk menentukan tanggal 1 Syawal ketika akan berhari raya Idul Fitri. Kedua; menyempurnakan bilangan hari pada bulan Sya'ban yaitu 30 hari untuk memulai bulan Ramadan menjadi 30 hari untuk berhari raya Idul Fitri. Teknik ini dikenal dengan istikmal yang harus ditempuh karena hilal tidak dapat dilihat saat rukyat pada malam ke 29 dari bulan Sya'ban atau Ramadan.

Petunjuk Nabi yang berkaitan dengan awal dan akhir Ramadan berdasarkan pada berbagai hadis tentang rukyat terjabar dalam tiga bentuk. Pertama; berupa perintah memulai dan mengakhiri puasa Ramadan berdasarkan status hilal dapat dirukyat, atau jika status hilal tidak dapat dirukyat dengan menggenapkan umur bulan yang sedang berjalan menjadi 30 hari. Kedua; berupa larangan memulai puasa pada bulan Ramadan selain dengan cara di atas. Ketiga; berupa amaliah nyata, yaitu isbat-isbat Nabi untuk memulai berpuasa Ramadan dan mengakhirinya berdasarkan laporan terlihatnya hilal yang berhasil dirukyat atau berdasarkan penggenapan (istikmal). ${ }^{37}$

Esensi hadis di atas terkait tentang proses penentuan awal bulan hijriah dengan metode pengamatan secara visual yang dicontohkan Nabi kepada penduduk Madinah. Rukyat dalam arti melihat secara visual lebih cocok bagi penduduk Madinah yang mayoritas agraris. Karena hadis tentang rukyat bernuansa Madinah dan perintah untuk berpuasa pun muncul di Madinah. ${ }^{38}$ Realitas di atas menunjukkan bahwa pilihan Nabi terhadap metode rukyat tanpa alat bantu yang berkaitan dengan penentuan awal bulan hijriah bukanlah sesuatu yang tiba-tiba, melainkan sikap yang bijak dari Nabi dalam menerjemahkan realitas sosial masyarakat Madinah saat itu. ${ }^{39}$

Rukyat yang dicontohkan Nabi secara visual merupakan justifikasi terhadap perilaku masyarakat Madinah. Dengan mempertimbangkan dua pemikiran, pertama; العبرة بعموم اللفظ لا بحصوص السبب bagi pendukung pemikiran tersebut, menjadikan makna rukyat tidak hanya dipahami dalam konteks penduduk Madinah tetapi melibatkan konteks penduduk Mekah ketika itu. Ini berarti rukyat tidak semata-mata melihat secara visual. Kedua; العبرة بحصوص السبب لابعموم اللفظ bagi pendukung pemikiran tersebut rukyat dapat bermakna tunggal yaitu melihat secara visual tanpa alat bantu karena menjadikan makna rukyat berdasarkan konteks Madinah.

Masa transisi dari rukyat konvensional ke rukyat tradisional ditandai dengan adanya alat bantu rukyat yang tergolong sederhana. ${ }^{40}$ Teknik rukyat pada periode ini sudah mulai terorganisir dari aspek peralatan dan data tertulis (perhitungan). Salah satu alat paling populer dan memiliki tingkat akurasi cukup tinggi pada periode ini adalah rubu' mujayyab. Alat bantu rukyat tradisional ini adalah alat yang dipakai oleh para pegiat rukyat ketika menentukan posisi dan mengukur ketinggian hilal sebagai penentuan awal bulan hijriah.

${ }_{37}$ Abd. Salam Nawai, Rukyat Hisab Di Kalangan NU Muhammadiyah Meredam Konflik Dalam Menetapkan Hilal (Surabaya: Diantama bekerjasama dengan LFNU Jawa Timur, 2004), 33.

38 Abdul Aziz Dahlan, Ensiklopedia Hukum Islam, I (Jakarta: Ictiar Baru van Hoeve, 1997), 1423.

39 Perbedaan letak geografis antara Mekah dan Madinah memiliki dampak terhadap pembentukan kebudayaan. Mekah merupakan kota dagang yang bertaraf internasional dan sentral peradaban Arab. Sedangkan Madinah merupakan daerah agraris dan subur. Pada masyarakat petani fenomena alam merupakan sesuatu yang penting bagi kehidupannya. Pergantian musim bisa diketahui melalui pendekatan empirik. Mereka bisa menjadikan bintang-bintang (nujum) sebagai pedoman dalam menentukan musim. Kondisi semacam ini berlaku juga pada masyarakat Arab Madinah yang cenderung memanfaatkan fenomena alam untuk menentukan pergantian musim. Sementara itu, Mekah yang notabene bernuansa metropolis dan sentral perdagangan internasional merupakan pintu gerbang masuknya peradaban lain sehingga epistemologi yang berkembang saat itu tidak semata-mata empiris tetapi juga rasional. Susiknan Azhari, Hisab \& Rukyat; Wacana Untuk Membangun Kebersamaan Di Tengah Perbedaan (Yogyakarta: Pustaka Pelajar, 2007), 66-67.

40 Abdul Hamied Husein, Melihat Bulan Dengan Kelat Bambu", Dalam Susiknan Azhari, Hisab \& Rukyat; Wacana Untuk Membangun Kebersamaan Di Tengah Perbedaan, n.d., 126-32. 


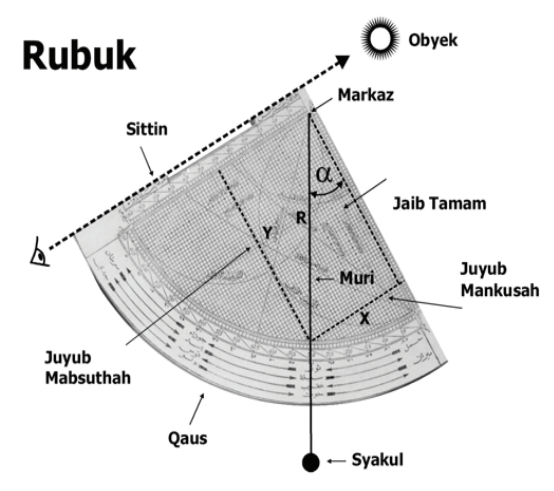

Gambar 1. Rubu’ Mujayyab

Istilah rubu' adalah alat berbentuk seperempat atau disebut juga dengan istilah kuadran. Rubu' bisa juga didefinisikan sebagai alat hitung untuk menentukan persoalan yang berkaitan dengan rumus segitiga bola. ${ }^{41}$ Dalam Ensiklopedi Hisab Rukyat, rubu' mujayyab merupakan suatu alat yang berbentuk seperempat lingkaran (90 derajat) digunakan untuk menghitung fungsi geniometris yang berguna untuk memproyerksikan peredaran benda-benda langit pada lingkaran vertikal. ${ }^{42}$ Alat ini merupakan salah satu instrumen astronomi yang bersifat tradisonal, yaitu suatu alat yang dapat difungsikan untuk menghitung ketinggian bintang di atas cakrawala atau alat yang berfungsi untuk menghitung dan memproyeksikan peredaran benda langit pada lingkaran vertikal termasuk Bumi, Bulan, dan Matahari..$^{43}$

\section{Rukyat Modern}

Perkembangan teknologi rukyat terjadi pada periode modern ${ }^{44}$ dengan ditandainya pemakaian teleskop sebagai cikal bakal teknologi optik yang dipelopori oleh Galileo Galilei pada awal abad ke $17 .{ }^{45}$ Pada periode ini, penggunaan alat fotografi untuk keperluan tertentu juga dapat mengisi kekurangmampuan mata untuk mengamati hilal. ${ }^{46}$

Mengenali sosok hilal pada saat rukyat bukan suatu perkara yang mudah. Sebelum rukyatulhilal dilaksanakan berbagai perlengkapan baik data perhitungan maupun perangkat teknologi harus disiapkan untuk membantu secara optimal terlihatnya hilal. Data perhitungan yang menunjukkan status hilal, baik posisi maupun ketinggiannya, juga berbagai peralatan teknologi yang digunakan untuk membantu melokalisir pandangan dan memperjelas obyek hilal. Diantara peralatan teknologi yang dapat digunakan untuk mengetahui posisi hilal adalah teleskop yang dapat digunakan saat rukyat.

${ }^{41}$ Hendro Setyanto, Rubu' Mujayyab (Jawa Barat: Pundak Saintifik, 2002), 1.

42 Susiknan Azhari, Ensiklopedi Hisab Dan Rukyat (Yogyakarta: Pustaka Pelajar, 2008), 181-82.

43 Muhyidin Khazin, Ilmu Falak Dalam Teori Dan Praktik (Yogyakarta: Buana Pustaka, 2004), 16.

44 Istilah modern didefinisikan sebagai pandangan atau kecenderungan untuk menyesuaikan tradisi dalam masalah agama agar harmonis dengan pemikiran modern. Periode ini ditandai dengan percaya pada sains, perencanaan dan kemajuan terhadap masa depan. Istilah modern lebih digunakan untuk menunjuk periode sejarah setelah abad pertengahan, yaitu dari tahun 1450 sampai sekarang. Koko Abdul Kodir, Metodologi Studi Islam (Bandung: Pustaka Setia, 2014), 260.

45 Moedji Raharto, Teknologi Optik Sebagai Pembantu Penetapan Awal Bulan Hijriyah/Qamariyah", Dalam Choirul Fuad YusufDan Bashori A Hakim, Hisab Rukyat Dan Perbedaannya (Jakarta: Proyek Peningkatan Pengkajian Kerukunan Hidup Umat Beragama, Puslitbang Kehidupan Beragama, Badan Litbang Agama dan Diklat Keagamaan, Departemen Agama RI, 2004), 145.

46 Badan Hisab dan Rukyat Departemen Agama, Almanak Hisab Rukyat, 205. 


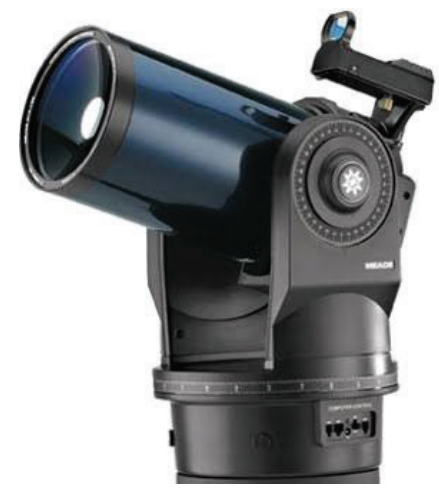

Gambar 2. Teleskop Rukyat

Munculnya ide penggunaan teleskop untuk kegiatan rukyatulhilal telah menjadi kenyataan sekaligus menimbulkan harapan dapat diatasinya kendala dalam rukyatulhilal. Namun, teleskop yang digunakan untuk kegiatan rukyatulhilal masih memiliki kelemahan dari sudut pandang astronomi yang diperkuat dengan adanya keraguan dari kalangan astronom dari Observatorium Bosscha. ${ }^{47}$ Teleskop khusus rukyat tidak jauh berbeda dengan teleskop pada umumnya. Perbedaannya paling menonjol dengan teleskop astronomi pada umumnya adalah sumbu geraknya. Sumbu gerak utama teleskop astronomi sejajar dengan sumbu rotasi Bumi agar bisa mengikuti gerak semu benda-benda langit dari timur ke barat. Sedangkan teleskop khusus rukyat dipasang secara alt-azimut, yang memungkinkan teleskop bergerak secara vertikal dan horizontal.

Fungsi utama teleskop selain sebagai pembesar penampakan objek adalah memperkuat cahaya objek dengan cara pengumpulan cahaya, baik dengan cermin cekung maupun lensa. Semakin besar diameter cermin atau lensa teleskop, semakin banyak cahaya yang dapat dikumpulkan sehingga makin besar kemampuan teleskop memperkuat cahaya dari objek benda-benda langit.

Hasil penelitian Schaefer yang mengacu pada hasil pengamatan hilal di berbagai tempat dengan mata visual dan menggunakan teleskop serta model teoritik yang dikembangkannya menunjukkan abhwa dengan teleskop pun cahaya hilal tetap tidak dapat dirukyat jika jarak sudut Matahari-Bulan kurang dari 7 derajat. ${ }^{48}$ Faktor lain lain yang menjadi kendala dalam rukyatulhilal adalah masalah beda kontras antara kecerlangan cahaya hilal dan cahaya syafak. Dengan menggunakan teleskop rukyat, baik kecerlangan cahaya hilal maupun cahaya syafak keduanya sama diperkuat, yang pada akhirnya kontrasnya pun sama dengan pengamatan tanpa alat bantu atau dengan mata visual. ${ }^{49}$ Kehadiran teleskop rukyat pun tidak mampu mengatasi kesulitan dalam rukyatulhilal.

\section{Rukyat Kontemporer}

Perkembangan rukyatulhilal pada masa kontemporer ${ }^{50}$ ditandai dengan munculnya berbagai instrumen digital kontemporer berupa perangkat lunak yang berfungsi untuk mengolah data

47 Thomas Djamaluddin, “Antara Limit Astronomis Dan Harapan Teleskop Rukyat Tantangan Rukyatul Hilal 1 Syawal 1416 H," 2003, 2.

48 B. E Schaefer, "Length of the Lunar Crescent," Q. Jl R. Astr. Soc., 1991, 265-77.

49 Thomas Djamaluddin dkk, Hisab Rukyat Di Indonesia Serta Permasalahannya, 95.

${ }_{50}$ Istilah kontemporer lebih tepat disebut modern tingkat lanjut yang menunjuk pada urutan kronologi waktu dari klasik ke skolastik kemudian disusul modern dan berujung pada kontemporer. Gerakan ini lahir di Eropa pada tahun 1960-an yang bermula dari bidang seni arsitektur dan merambah ke dalam bidang lain, baik sastra, ilmu sosial, gaya hidup, filsafat maupun agama M Amin Abdullah, Epistemologi Keilmuan Studi Hukum Islam Dalam Merespon Globalisasi, Jurnal Ilmu Syari'ah Dan Hukum Vol., vol. $46,2012,341$. 
rukyat berupa citra hilal. Rukyat yang dilakukan oleh para pegiat rukyat untuk menentukan awal bulan hijriah meskipun sudah dilakukan menggunakan alat bantu rukyat modern seperti teleskop rukyat, namun penilaian ada atau tidaknya hilal sebagai bukti empirik masih dipertanyakan karena dilaksanakan secara subjektif. Rukyat yang dilaksanakan tidak mendapatkan bukti objektif berupa citra hilal..$^{51}$

Rukyatulhilal dengan bantuan peralatan seperti teleskop rukyat yang telah dilengkapi kamera fotografi atau detektor elektronik pada prinsipnya dapat menolong mengenali sosok hilal yang sangat redup jika sensitivitasnya lebih baik daripada sensitivitas mata. Pada kondisi jarak sudut antara Matahari dan Bulan kurang dari 7 derajat hilal dapat terdeteksi. Cara yang ditempuh yaitu meningkatkan kontras cahaya hilal dalam melakukan olah data melalui digital imaging.

Teknologi digital imaging maupun proses olah citra menggunakan perangkat komputer secara umum sudah sering digunakan oleh para astronom untuk meningkatkan kontras yang lemah maupun mendeteksi objek dari benda-benda langit yang sangat redup, langkah ini dapat ditempuh untuk mengatasi kelemahan teleskop rukyat. Rukyat untuk menentukan posisi dan keberadaan hilal dapat diproses dengan berbagai instrumen digital seperti perangkat lunak astronomi agar validitas rukyat semakin meningkat serta menghilangkan keraguan. ${ }^{52}$

Rukyatulhilal dilakukan pada sore hari, tepat setelah Matahari terbenam. Hal ini disebabkan posisi hilal pada saat fase bulan baru berdekatan dengan Matahari. Kecerlangan cahaya syafak mempengaruhi prediksi visibilitas hilal, karena dapat mempengaruhi kontras antara hilal dengan latar depannya. Menurut Bruin, kecerlangan cahaya syafak tersebut sebagai fungsi kedalaman Matahari terbenam. ${ }^{53}$

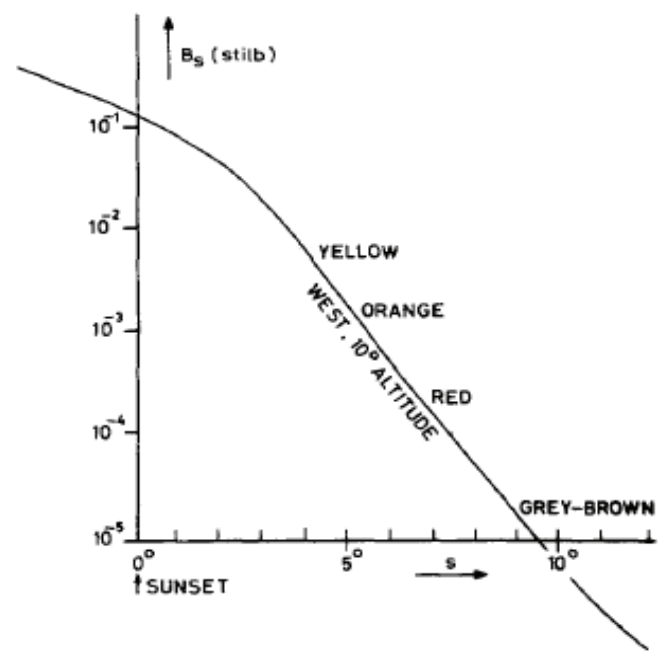

Gambar 3. Diagram Cahaya Syafak

Berdasarkan kurva kecerlangan cahaya syafak pada gambar 3, Bruin menunjukkan kecerlangan langit barat pada ketinggian 10 derajat, sebagai fungsi sudut depresi Matahari di bawah horizon (s). Bruin mengasumsikan bahwa kecerlangan cahaya syafak dianggap sama pada ketinggian yang sama.

\footnotetext{
51 Dkk, Rukyat Dengan Teknologi; Upaya Mencari Kesamaan Pandangan Tentang Penentuan Awal Ramadhan Dan Syawal, 25.

52 Legault, "Astrophotography," 120.

53 Frans Bruin, “The First Visibility of Lunar Crescent," Vistas in Astronomy 21, 1977, 331-58.
} 
Mata sebagai alat deteksi dalam rukyatulhilal, mempunyai batas kemampuan dalam kepekaan terhadap benda terang maupun kontras dengan latar depan. Meskipun kemampuan ini berbeda-beda setiap pengamat, tapi pada umumnya perbedaan tersebut sangat kecil sehingga dapat diturunkan suatu kemampuan standar. Dalam pengamatan langit malam, kemampuan mata bisa mendeteksi bintang yang sampai batas terendah 6 magnitudo. Sedangkan jika pengamatan dibatasi pada arah pandang tertentu saja (misalnya pengamatan dilakukan dari bawah sumur yang sangat dalam) batas ambang kemampuan mata bisa meningkat sampai 8.5 magnitudo. ${ }^{54}$

Rukyatulhilal dengan mata visual mensyaratkan nilai kontras cahaya hilal atau obyek langit yang tinggi nilai iluminasi hilal minimal 1.5\%. Kelemahan rukyatulhilal dengan mata visual adalah hilal yang dilihat oleh mata visual tidak dapat direkam bahkan diulang, sehingga data rukyatulhilal terbatas pada kesaksian seseorang yang melihat hilal hanya berani disumpah, maka analisis secara kuantitatif pun sulit dibuktikan.

Rukyatulhilal yang dilaksanakan sore hari dipengaruhi oleh cahaya syafak. Pada saat cahaya syafak terang diafragma mata mengecil dan berarti makin sedikit foton cahaya hilal yang sampai ke retina mata karena cahaya hilal semakin sulit untuk dapat dikenali oleh mata pengamat. ${ }^{55}$ Pada saat meredupnya cahaya syafak diafragma mata pengamat akan membesar. Membesarnya diafragma mata berarti semakin banyak foton dari cahaya hilal yang bisa dikumpulkan oleh lensa mata sehingga mempunyai kesamaan untuk dapat dikenali oleh mata jika jumlah foton cahaya sudah melewati suatu batas ambang pengenalan objek seperti hilal.

Mata sebagai alat detektor utama dalam rukyatulhilal tanpa alat bantu rukyat tidak memiliki kesanggupan memilih cahaya hilal di samping kemilaunya cahaya syafak. Karena, mata mempunyai batas kepekaan yang sama antara daerah cahaya kuning (visual), kecuali pada malam hari sensitivitas bergeser ke arah merah. Kontras cahaya hilal terhadap latar depan berupa cahaya syafak sangat lemah. Rukyatulhilal adalah masalah membedakan antara kontras cahaya hilal yang sangat tipis dan redup dengan cahaya syafak yang masih cukup terang. Karena mata tidak sanggup membedakannya, maka kualitas alat bantu optik dalam rukyatulhilal penting digunakan dengan demikian dapat dicapai objektivitas hasil rukyatulhilal. ${ }^{56}$

\section{Rukyatulhilal dengan Teknologi}

Informasi obyek langit dalam hal ini adalah hilal, diteruskan oleh kurir yang disebut foton. Kurir informasi berawal dari permukaan Bulan yang disinari oleh cahaya Matahari, berpropagasi melewati ruang antar Bulan dan Bumi, menembus turbulensi atmosfer Bumi, masuk melalui perangkat keras (hardware) berupa kamera, teleskop, mounting, dan perlengkapan lain yang pada akhirnya menghasilkan sebuah citra. ${ }^{57}$ Informasi cahaya hilal yang diperoleh selain bergantung terhadap alat bantu rukyat juga bergantung terhadap prosentase iluminasi cahaya hilal, akibat gangguan dari cahaya syafak menjadikan cahaya hilal redup bahkan tidak terlihat.

\footnotetext{
54 Purwanto, "Visibilitas Hilal Sebagai Acuan Penyusunan Kalender Islam” (Institut Teknologi Bandung, 1992), 24-25.

55 Moedji Raharto, Peningkatan Profesionalisme Pengamatan Hilal”, Dalam Dasar-Dasar Sistem Kalender Bulan Dan Kalender Matahari (Bandung: Program Studi Astronomi Fakultas Matematika dan Ilmu Pengetahuan Alam Institut Teknologi Bandung, 2009), 188.

56 Raharto, Teknologi Optik Sebagai Pembantu Penetapan Awal Bulan Hijriyah/Qamariyah", Dalam Choirul Fuad Yusuf Dan Bashori A Hakim, Hisab Rukyat Dan Perbedaannya, 146.

57 Dhani Herdiwijaya, "Prosedur Sederhana Pengolahan Citra Untuk Pengamatan Hilal," in Seminar Nasional Hilal 2009 (Bandung: Observatorium Bosscha, FMIPA-ITB, 2009), 110.
} 
Cahaya hilal redup dan tidak terlihat akibat turbulensi atmosfer ataupun ketidaksempurnaan alat bantu rukyat. Pengamatan visual dan tidak didukung dengan alat bantu rukyat, sulit untuk mengenali hilal. Maka penggunaan perangkat teknologi digital imaging penting dilakukan dalam rangka pengolahan citra hilal yang bertujuan untuk meningkatkan kontras cahaya hilal yang redup, tipis, dan tidak bisa terlihat secara visual. Berikut adalah tahapan proses teknologi digital imaging dalam rukyatulhilal:

\section{a. Menyiapkan Hardware}

Perangkat keras (hardware) yang perlu disiapkan sebelum rukyatulhilal dilakukan terdiri dari peralatan utama yaitu teleskop, tripod, mounting, dan kamera digital direkomendasikan DSLR EOS tipe 60Da yang khusus untuk fotografi astronomi. Perangkat keras lain sebagai peralatan penunjang yaitu webcam, laptop, filter matahari. Tidak kalah penting adalah peralatan broadcast/ live terdiri dari jaringan internet, aplikasi streaming, dan LCD TV/LCD monitor.

Sebelum proses perekaman dimulai teleskop perlu disesuaikan agar tepat pada posisi hilal. Karena hilal yang akan direkam adalah objek yang redup dan tipis bahkan belum tentu dapat diamati menggunakan mata visual. Penyesuaian teleskop dilakukan minimal sebelum terbenamnya Matahari dengan cara mengarahkan teleskop ke arah Matahari yang sudah dipasang filter. Selanjutnya teleskop diarahkan dengan memposisikan Matahari tepat di tengah medan pandang eyepiece dengan mengatur fokusnya sebaik mungkin. Direkomendasikan menggunakan tabung yang didalamnya ada beberapa sirip dengan konfigrasi tertentu yang diletakkan di depan lensa obyektif untuk mengurangi sudut cahaya, dengan demikian cahaya Matahari dapat diminimalisir dan kontras cahaya hilal dapat ditingkatkan. ${ }^{58}$

Setelah perangkat keras dipasang dan dijalankan dengan sempurna, maka harus dipastikan hilal sebagai objek utama dalam rukyatulhilal sudah teridentifikasi ada dalam frame citra atau video rekaman, meskipun secara visual hilal belum dan atau tidak terlihat.

\section{b. Menyiapkan Software}

Setelah data diperoleh melalui perangkat keras baik berupa rekaman video atau citra hilal dalam jumlah frame yang cukup banyak, tahap selanjutnya adalah melakukan olah citra dengan perangkat lunak (software). Tujuan dari proses pengolahan citra hilal adalah menggali sumber informasi sebanyak mungkin dari cahaya hilal sebagai obyek langit yang mungkin tersembunyi akibat turbulensi atmosfer maupun terbatasnya kemampuan alat bantu rukyat yang digunakan.

Teknologi digital imaging memiliki peran signifikan dalam mengolah citra hilal. Teknologi ini berupa perangkat lunak yang dapat digunakan dengan maksimal untuk mengolah data rukyat. Melalui kerangka kerja teknologi digital imaging, kecerlangan cahaya hilal yang redup dapat ditingkatkan kontrasnya, sehingga dapat dilihat dengan mudah secara visual.

Dalam hal ini, perangkat lunak yang digunakan untuk olah citra hilal memiliki beberapa tipe, yaitu gratis atau opensource dengan pertimbangan harus memiliki kelengkapan menu yang baik seperti halnya perangkat lunak atau software IRIS versi 5.59 terakhir kanal ini memiliki frekuensi revisi yang cukup tinggi. Adapun olah data rukyat dengan software tersebut dapat ditempuh dengan langkah berikut:

\footnotetext{
58 Hendra Gunawan Dhani Herdiwijaya, Mitra Djamal, "Design of Mobile and Robotic Observing System with Special Telescope Baffle for Searching Young Lunar Crescent," Jurnal Otomasi, Kontrol, Dan Instrumentasi 4, no. 1 (2012), 3; Ahmad Junaidi, "Memadukan Rukyatulhilal Dengan Perkembangan Sains," MADANIA 22, no. 1 (2018), 154.
} 
Pertama, membuat directory file atau folder yang berfungsi untuk mempermudah pengelompokan dan penyimpanan file video rekaman dan frame image melalui langkah: klik file - pilih settings - klik working path, maka akan diarahkan pada folder yang dituju sebagai tempat kerja dan media penyimpanan.

Kedua, konversi video rekaman menjadi frame image. Langkah ini berfungsi untuk memecah file rekaman video yang berekstensi avi menjadi image. Langkah ini dapat ditempuh: klik file - pilih AVI conversion - klik select maka secara otomatis akan diarahkan pada directory file yang di dalamnya sudah terdapat video rekaman. Setelah pilih video rekaman klik open pada exported image type pilih black \& white. Sedangkan pada panchro band output file name atur sistem penamaan dan penomoran dengan mengeketikan nama misal (analisis-) tanda (-) digunakan untuk memisahkan nama dengan penomoran dalam frame image hasil konversi, selanjutnya klik convert maka muncul intruksi yang memberikan informasi tentang video rekaman tersebut akan dipecah menjadi berapa frame, perkiraan waktu yang ditempuh, ukuran file, dan kapasitas penyimpanan yang diperlukan. Setelah klik yes maka pemecahan video rekaman menjadi frame image pun berlangsung. Ketika proses konversi video rekaman menjadi frame image dijalankan, maka proses konversi pun berjalan tergantung dengan kapasitas file video rekaman yang dikonversi. Semakin besar kapasitas video rekaman, maka semakin banyak jumlah frame yang dihasilkan.

Ketiga, melakukan penumpukan frmae image dari beberapa frame image menjadi satu. Langkah ini ini disebut stacking yaitu menggabungkan frame citra hilal menjadi satu. Langkah yang ditempuh adalah klik processing - pilih add a squence, pada input generic name ketikan nama sesuai dengan penamaan diawal (analisis-), isikan jumlah frame image yang akan distacking dengan catatan tidak melebihi jumlah dari frame image hasil konversi secara keseluruhan. Misal hanya 200 frame image yang akan distacking. Selanjutnya pilih median yang berfungsi agar hilal yang terlihat pada frame image tersebut berada pada posisi sejajar dengan frame, selanjutnya klik ok dan proses penumpukan 200 frame image pun berlangsung.

Langkah selanjutnya adalah menyimpan frame image yang sudah distacking dengan langkah klik file selanjutnya pilih save kemudian pada file name tuliskan nama file yang dikehendaki misalnya (hasilanalisis), pada save as type pilih jenis BMP untuk mendapatkan frame image hilal dengan resolusi tinggi.

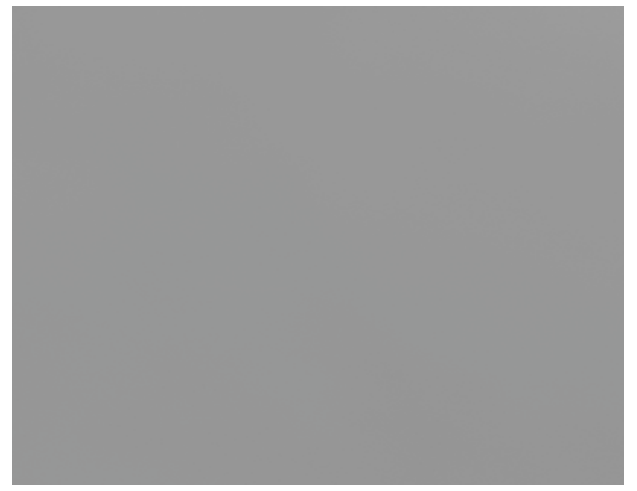

Gambar 4. Penumpukkan Citra Hilal 
Citra hilal hasil konversi dari video rekaman ke frame image hasil distacking jika dilihat secara visual, hilal tidak terlihat. Tapi sudah dipastikan bahwa hilal berada dalam frame tersebut. Agar hilal pada frame tersebut dapat dilihat secara visual, maka kontras hilal harus diidentifikasi berdasarkan panjang gelombang cahaya. Langkah ini berfungsi untuk menentukan sumber cahaya paling kuat, setelah cahaya syafak dieliminasi cahaya hilal menghasilkan sumber gelombang foton yang cukup banyak. Hal ini dapat dibuktikan dengan membuat plot konfigurasi cahaya hilal pada frame image hasil stacking. Langkah ini dapat dikerjakan dengan perangkat lunak GIMP versi 2.10.12 yang dapat memberikan informasi awal sebagai titik konfigurasi sumber cahaya hilal paling kuat dengan tahapan klik file, open dan pilih file frame image yang akan diolah. Selanjutnya klik colors pilih levels maka tampil beranda adjust color levels pada menu input level tampak terlihat panjang gelombang cahaya hilal pada satu titik. Langkah ini hanya berfungsi untuk meningkatkan atau memperkuat citra hilal yang sudah dipilih memiliki kualitas baik hasil stacking dengan memanfaatkan menu penangkal berupa peningkatan kontras (contrast) maupun kecerlangan (brightness).

Langkah ini memiliki bertujuan untuk menghilangkan adanya gangguan seperti embun, partikel debu, dan kotoran yang menempel pada lensa teleskop maupun kamera. Adapun citra hilal yang memiliki keberadaan ghost image atau gambar yang merusak kecerlangan cahaya tidak dapat diolah. Maka cukup citra hilal yang memungkinkan bisa diolah saja yang diambil dengan kriteria bersih dari gangguan tersebut. Selain itu, tahapan ini juga berfungsi untuk menaikkan nilai kontras dengan langkah arahkan kurso pada menu input levels tersebut menuju titik panjang gelombang, kemudian klik ok, file, dan export as untuk menyimpan frame image. Hasil akhir dari analisis citra ini menunjukkan bahwa cahaya syafak sebagai isu utama yang menggangguan dalam rukyatulhilal dapat dieliminasi yang dibuktikan dengan terlihatnya hilal secara visual.

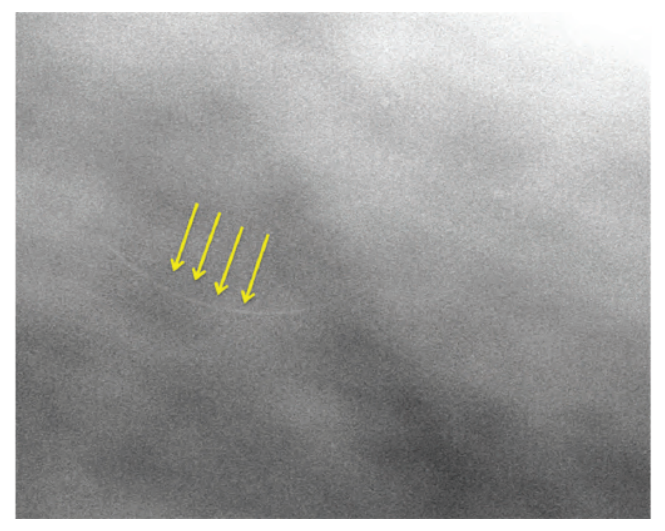

Gambar 5. Hilal Kasat Mata

\section{Respon Ulama Fikih}

Respon fikih terhadap perkembangan penggunaan alat teknologi dalam rukyatulhilal penting dirumuskan. Hal ini sejalan dengan kaidah ushul fikih bahwa status hukum penggunaan peralatan sama dengan status hukum tujuan, yaitu wasilah atau perantara mempunyai hukum sesuai dengan hukum tujuan. Bahwa hukum penggunaan peralatan sama dengan hukum tujuan. Lebih spesifik, hukum rukyat adalah wajib, maka peralatan dan perangkat dalam rukyatulhilal menjadi wajib. Hal ini sejalan dengan kaidah fikih: 
Pengolahan citra hanya membantu memperkuat atau meningkatkan kontras dengan menumpuk beberapa citra yang direkam. Semula dalam bentuk video yang dipecah dalam jumlah frame citra yang banyak menjadi satu citra yang menunjukkan citra hilal yang tegas. Berdasarkan kaidah fikih di atas, maka hasil rukyatulhilal yang mengandalkan olah citra hilal digital imaging dapat diterima dan dibenarkan, karena tujuan utama penggunaan alat bantu rukyat tersebut adalah untuk memudahkan rukyatulhilal sebagai pedoman dalam penentuan awal bulan hijriah.

Ulama fikih yang memberikan respon terhadap penggunaan teknologi dalam kegiatan rukyatulhilal dapat dikategorikan menjadi dua yaitu pendapat ulama klasik dan kontemporer. Menurut ulama klasik seperti Ahmad Ibnu Hajar al-Haitami, Abdul Hamid as-Syarwani, dan Muhammad Bakhit al-Muti'i memberikan respon positif terkait penggunaan teknologi dalam rukyatulhilal meski melihat langsung tanpa alat bantu rukyat lebih diutamakan.

Dalam konteks fikih sejatinya rukyatulhilal harus dilakukan dengan mata visual (naked eye) tanpa alat bantu rukyat. Menurut al-Haitami penggunaan alat bantu dalam rukyatulhilal hanya diperbolehkan seperti kaca yang dapat memantulkan cahaya. Sejalan dengan hal tersebut, penggunaan alat bantu seperti teleskop yang berfungsi memantulkan cahaya pun masih diperbolehkan dengan tujuan untuk memperjelas cahaya hilal. ${ }^{60}$

Menurut as-Syarwani rukyatulhilal lebih utama dilakukan tidak menggunakan alat bantu rukyat. Namun hanya diperkenankan menggunakan alat bantu rukyat seperti air, ballur, atau suatu alat yang dapat mendekatkan yang jauh dan yang membesarkan yang kecil dalam rukyatulhilal. ${ }^{61}$ Sedangkan menurut al-Muti'i penggunaan alat bantu dalam rukyatulhilal diperkenankan untuk digunakan seperti teropong pembesar yang berfungsi untuk melihat benda yang jauh atau kecil yang tidak memungkinkan untuk dilihat dengan mata visual. Pendapat al-Muti'i tersebut pernah dipraktekkan dengan diterimanya kesaksian seseorang yang melihat hilal meski dengan alat sederhana tersebut. ${ }^{62}$ Karena pada prinsipnya rukyatulhilal dengan alat bantu rukyat seperti teleskop dapat diqiyaskan dengan fungsi kacamata yang dipakai untuk membaca.

Sedangkan ulama kontemporer yang memberikan respon terhadap penggunaan alat bantu untuk rukyatulhilal adalah ulama yang pemikirannya concern terhadap dinamika hisab dan rukyat seperti Thomas Djamaluddin. Menurutnya, penggunaan alat bantu rukyat sangat dianjurkan untuk menambah keyakinan bahwa objek yang diamati adalah hilal bukan objek lain yang menyerupai hilal. Tujuan dari rukyat bil fili adalah mencari bukti hilal, yang juga lebih meyakinkan dengan alat bantu rukyat mempunyai kedudukan yang sama degan rukyat bil fi'li, bahkan buktinya lebih akurat. Adapun perbedaannya hanya terletak pada bukti yang diperoleh. Jika rukyat bil fi'li buktinya disimpan di otak pengamat dan dinyatakan secara lisan dengan sumpah di hadapan hakim. Sedangkan rukyat dengan alat bantu bukti citra hilal bisa ditunjukan di layar atau dicetak untuk meyakinkan hakim yang melakukan penyumpahan terhadap orang yang melihat hilal. Kedudukan kesaksian dari kedua hal ini adalah sama karena bukti citra sangat kuat dan tidak terbantahkan. ${ }^{63}$

59 Ibn Qayyim Al-Jauziyah, I'lamul Muwaqi in 'An Rab Al-Alamin (Beirut: Dar al-Fikr, n.d.).

60 Ahmad Ibnu Hajar al-Haitami, Hamisy Hawasyī Tuhfatul Muhtāj bi Syarhil Minhaj, (Mesir: Mushthafa Muhammad, tt.), 371-372.

${ }_{61}$ Abdul Hamid asy-Syarwani, Hawāsyī Tuhfatul Muhtāj bi Syaḥril Minhaj, (Mesir: Mushthafa Muhammad, tt.), 372.

62 Muhammad Bukhit al-Muti'i, Irsyādu Ahli al-Millati Ilā Iśba'ati al-Ahillah, (Mesir: Kurdistan al-Ilmiyah, 1329), 293-294.

63 Riza Afrian Mustaqim, "Pandangan Ulama Terhadap Image Processing Pada Astrofotografi di BMKG Untuk Rukyatul Hilal”, Al-Marshad: Jurnal Astronomi Islam dan Ilmu-Ilmu Berkaitan, doi: https://doi.org/10.30596/jam.v4i1.1937, 2018. 


\section{Penutup}

Penggunaan teleskop dalam rukyatulhilal tidak dapat memcahkan masalah yaitu terlihatnya hilal. Karena rukyat dengan bantuan teleskop tidak dapat memperoleh cahaya hilal akibat adanya kontras kecerlangan cahaya syafak yang mengalahkan cahaya hilal. Teknologi yang memungkinkan dapat digunakan dalam rukyatulhilal adalah olah data rukyat yang bertujuan agar cahaya hilal dapat terlihat dengan mata visual. Olah data rukyat dapat ditempuh dengan metode digital imaging yaitu melakukan analisis terhadap citra hilal dengan memanfaatkan perangkat lunak yang bertujuan untuk meningkatkan kontras cahaya hilal agar validitas rukyat dapat dipertanggungjawabkan secara empirik.

Rukyatulhilal jarang dilakukan secara ilmiah, yaitu melakukan analisis terhadap data rukyat berupa citra hilal dengan bantuan teknologi digital imaging. Pada umumnya yang diandalkan adalah sumpah atas kesaksian seseorang melihat hilal. Pengolahan data rukyat sebagai bukti empiric penting dilakukan terlebih jika status hilal yang gagal diamati secara visual tanpa alat bantu rukyat, tetapi berhasil dideteksi dengan pengolahan citra digital imaging. Keraguan atas kesaksian seseorang melihat hilal sudah sepatutnya direspon dengan mengkaji hilal secara fisis. Sehingga, dapat menghilangkan keraguan dalam penentuan awal hijriah yang sarat dengan pelaksanaan ibadah.

Dalam menyikapi perkembangan teknologi dalam rukyatulhilal, hampir seluruh ulama fikih menyatakan kebolehannya terkait penggunaan teknologi modern yang bertujuan membantu memudahkan proses rukyatulhilal, terutama dalam hal memperjelas citra hilal atau memperjelas objek pandang hilal agar dapat dilihat dengan mata visual.

\section{DAFTAR PUSTAKA}

Abdul Hamid asy-Syarwani. Hawasyī Tuhfatul Muhtāj bi Syarhil Minhāj. Mesir: Mushthafa Muhammad, tt.

Abdullah, M Amin. Epistemologi Keilmuan Studi Hukum Islam Dalam Merespon Globalisasi. Jurnal Ilmu Syari'ah Dan Hukum Vol. Vol. 46, 2012.

Ahmad Ibnu Hajar al-Haitami. Hamisy Hawāsyi Tuhfatul Muhtaj bi Syarhil Minhaj. Mesir: Mushthafa Muhammad, tt.

Ahmad Warson Munawwir. Al-Munawwir Kamus Arab-Indonesia. Surabaya: Pustaka Progresif, 1997.

Al-'Askarî, Abû Hilâl al-hasan bin 'Abdillâh bin Sahal bin Sa'îd bin Yahyâ bin Mahrân. Mu'jam Al-Furûq Al-Lughawîyah. Muassasah al-Nasyr al-Islâmî, 1412.

Al-Bukhari, Muhammad bin Isma 'il. Matn Al-Bukhari. Mesir: Dar Ihya 'al-'Arabiyyah, n.d.

al-Fairuz Abadi. Al-Qamus Al-Muhit. Beirut: Dar al-Fikr, 1995.

Al-Farahidi, al-Khalil Ibnu Ahmad. Kitab Al-'Ayn. Beirut: Dar Ihya' al-Turas al-'Arabi, n.d.

Al-Fayyûmî, Ahmad bin Muhammad bin 'Alî al-Maqrî. Al-Misbâh Al-Munîr Fî Gharî̉ Al-Syarh Al-Kabîr Li Al-Râfi'î. Beirut: al-Maktabah al-'Ilmîyah, n.d.

Al-Isbahani, Ragib. Al-Mufradat. Damascus: Dar al-Qalam, 1992.

Al-Jauziyah, Ibn Qayyim. I'lamul Muwaqi'in 'An Rab Al-Alamin. Beirut: Dar al-Fikr, n.d.

Azhari, Susiknan. Ensiklopedi Hisab Dan Rukyat. Yogyakarta: Pustaka Pelajar, 2008. 
B. Lewis, dkk. The Encyclopedia of Islam. III. Leiden: E.J. Brill, 1971.

Badan Hisab dan Rukyat Departemen Agama. Almanak Hisab Rukyat. Jakarta: Direktorat Bimbingan Masyarakat Islam Kementerian Agama RI, 2010.

Bruin, Frans. "The First Visibility of Lunar Crescent.” Vistas in Astronomy 21, 1977.

Dahlan, Abdul Aziz. Ensiklopedia Hukum Islam. I. Jakarta: Ictiar Baru van Hoeve, 1997.

Departemen Agama. Pedoman Perhitungan Awal Bulan Qamariyah. Jakarta: Direktorat Jenderal Pembinaan Kelembagaan Agama Islam, 1995.

Departemen Agama RI. Pedoman Teknik Ru'yat. Jakarta: Proyek Pembinaan Badan Peradilan Agama, 1994.

Departemen Pendidikan dan Kebudayaan. Kamus Besar Bahasa Indonesia. Edited by Balai Pustaka. Jakarta, 1989.

Dhani Herdiwijaya. "Prosedur Sederhana Pengolahan Citra Untuk Pengamatan Hilal." In Seminar Nasional Hilal 2009. Bandung: Observatorium Bosscha, FMIPA-ITB, 2009.

Dhani Herdiwijaya, Mitra Djamal, dan Hendra Gunawan. "Design of Mobile and Robotic Observing System with Special Telescope Baffle for Searching Young Lunar Crescent." Jurnal Otomasi, Kontrol, Dan Instrumentasi 4, no. 1 (2012).

Dkk, Harun Nasution. Ensiklopedi Islam Indonesia. Cet. I. Jakata: Djambatan, 1992.

Dkk, S. Farid Ruskanda. Rukyat Dengan Teknologi; Upaya Mencari Kesamaan Pandangan Tentang Penentuan Awal Ramadhan Dan Syawal. Jakarta: Gema Insani Press, 1994.

Endarto, Danang. Pengantar Kosmografi. Surakarta: Lembaga Pengembangan Pendidikan UNS bekerjasama dengan UNS Press, 2005.

Hakim, Choirul Fuad Yusuf dan Bashori A. Hisab Rukyat Dan Perbedaannya. Jakarta: Proyek Peningkatan Pengkajian Kerukunan Hidup Umat Beragama, Puslitbang Kehidupan Beragama, Badan Litbang Agama dan Diklat Keagamaan, Departemen Agama RI, 2004.

Hans Wehr. Arabic-English Dictionary. 4th ed. Germany: Otto Harrassonitz, 1994.

Husein, Abdul Hamied. Melihat Bulan Dengan Kelat Bambu", Dalam Susiknan Azhari, Hisab \& Rukyat; Wacana Untuk Membangun Kebersamaan Di Tengah Perbedaan, n.d.

Junaidi, Ahmad. "Memadukan Rukyatulhilal Dengan Perkembangan Sains.” Jurnal MADANIA 22, no. 1 (2018).

Khazin, Muhyidin. Ilmu Falak Dalam Teori Dan Praktik. Yogyakarta: Buana Pustaka, 2004.

Kodir, Koko Abdul. Metodologi Studi Islam. Bandung: Pustaka Setia, 2014.

Legault, Thierry. “Astrophotography.” Paris: Groupe Eyrolles, 2013.

Ma'luf, Lois. Al-Munjid Fî Al-Lughah Wa Al-A'lâm. Beirut: Dâr al-Masyriq, 1989.

Ma'ruf Amin. Rukyat Untuk Penentuan Awal Dan Akhir Ramadan Menurut Pandangan Syari'ah Dan Sorotan IPTEK", Dalam Selayang Pandang Hisab Rukyat. Jakarta: Direktorat Jenderal Bimas Islam dan Penyelenggaraan Haji Direktorat Pembinaan Peradilan Agama, 2004.

Manzûr, Ibnu. Lisân Al-'Arab. 17th ed. Kairo: Dâr al-Ma'ârif, n.d.

Masroerie, A. Ghazali. Penentuan Awal Bulan Qamariyah. Jakarta: Lajnah Falakiyah Nahdlatul Ulama, 2011. 
Moedji Raharto. Peningkatan Profesionalisme Pengamatan Hilal", Dalam Dasar-Dasar Sistem Kalender Bulan Dan Kalender Matahari. Bandung: Program Studi Astronomi Fakultas Matematika dan Ilmu Pengetahuan Alam Institut Teknologi Bandung, 2009.

Muhammad Baqir Behbudi. The Quran A New Interpretation. 1st ed. London: Curzon press, 1997.

Muhammad Bukhit al-Muti'i. Irsyadu Ahli al-Millati Ila Istba'ati al-Ahillah. Mesir: Kurdistan al-Ilmiyah, 1329.

Muhdlor, Atabik Ali dan Ahmad Zuhdi. Kamus Kontemporer Arab-Indonesia. Yogyakarta: Multi Gaya Grafika, 1998.

Muhyiddin Khazin. Ilmu Falak Dalam Teori Dan Praktik. Yogyakarta: Buana Pustaka, 2004.

---. Kamus Ilmu Falak. Yogyakarta: Buana Pustaka, 2014.

Nawai, Abd. Salam. Rukyat Hisab Di Kalangan NU Muhammadiyah Meredam Konflik Dalam Menetapkan Hilal. Surabaya: Diantama bekerjasama dengan LFNU Jawa Timur, 2004.

Purwanto. "Visibilitas Hilal Sebagai Acuan Penyusunan Kalender Islam.” Institut Teknologi Bandung, 1992.

Raharto, Moedji. Teknologi Optik Sebagai Pembantu Penetapan Awal Bulan Hijriyah/Qamariyah", Dalam Choirul Fuad Yusuf Dan Bashori A Hakim, Hisab Rukyat Dan Perbedaannya. Jakarta: Proyek Peningkatan Pengkajian Kerukunan Hidup Umat Beragama, Puslitbang Kehidupan Beragama, Badan Litbang Agama dan Diklat Keagamaan, Departemen Agama RI, 2004.

Riza Afrian Mustaqim. "Pandangan Ulama Terhadap Image Processing Pada Astrofotografi di BMKG Untuk Rukyatul Hilal”. Al-Marshad: Jurnal Astronomi Islam dan Ilmu-Ilmu Berkaitan, doi: https:// doi.org/10.30596/jam.v4i1.1937, 2018.

Ruskanda, Farid. 100 Masalah Hisab \& Rukyat; Telaah Syariah, Sains Dan Teknologi. Jakarta: Gema Insani Press, 1996.

Schaefer, B. E. "Length of the Lunar Crescent." Q. Jl R. Astr. Soc., 1991, 265-77.

Setyanto, Hendro. Rubu' Mujayyab. Jawa Barat: Pundak Saintifik, 2002.

Sudibyo, Mutoha Arkanuddin dan Muh. Ma'rufin. "Kriteria Visibilitas Hilal Rukyatul Hilal Indonesia (RHI) (Konsep, Kriteria, Dan Implementasi)." Al-Marshad: Jurnal Astronomi Islam Dan Ilmu-Ilmu Berkaitan 1, no. 1 (n.d.).

Susiknan Azhari. Ensiklopedi Hisab Dan Rukyat. Yogyakarta: Pustaka Pelajar, 2008.

---. Hisab \& Rukyat; Wacana Untuk Membangun Kebersamaan Di Tengah Perbedaan. Yogyakarta: Pustaka Pelajar, 2007.

---. Ilmu Falak; Perjumpaan Khazanah Islam Dan Sains Modern. Yogyakarta: Suara Muhammadiyah, 2007.

Thomas Djamaluddin. “Antara Limit Astronomis Dan Harapan Teleskop Rukyat Tantangan Rukyatul Hilal 1 Syawal 1416 H,” 2003.

Thomas Djamaluddin dkk. Hisab Rukyat Di Indonesia Serta Permasalahannya. Jakarta: Badan Meteorologi Klimatologi dan Geofisika, 2010.

Tono Saksono. Mengkompromikan Rukyat \& Hisab. Jakarta: Amythas Publicita, 2007. 